\title{
A ROMAN PERSPECTIVE ON THE ADVANTAGE FOR CREDITORS REQUIREMENT IN SOUTH AFRICAN INSOLVENCY LAW
}

\author{
By Tanya Rheeder*
}

\section{Introduction}

Ancient Rome, dating from 509 BC, a time which unveiled the early Roman republic, developed a unique and invaluable debt collecting system. This primitive society birthed and nurtured something which is known to us today as insolvency law.

South African insolvency law, an offspring of ancient Rome, is laced with many formalities and requirements, all of which were implemented to create fair distribution of the proceeds of a debtor's property in a situation where the debtor does not have sufficient assets to settle all his debts. ${ }^{1}$ In return the debtor obtains a fresh start, as all his previous debt is discharged. ${ }^{2}$

Sections 12(1)(c) and section 6(1) of the Insolvency $\mathrm{Act}^{3}$ contain a very similar and intriguing requirement. These sections state, respectively, that in the case of a compulsory sequestration, there has to be reason to believe that it will be to the advantage of the creditors if the debtor is sequestrated; and in the case of a voluntary sequestration, that it will be to the advantage of the creditors if the debtor is sequestrated.

The discussion to follow aspires to take a closer look at the birth of the Roman debt collecting system and trace the development for approximately a thousand years, with the aim of clarifying the present state of the law by showing its evolution over time. ${ }^{4}$ However, before venturing into the depths of ancient Rome, a thorough understanding of the application of Roman law in South Africa is crucial.

* LLB (University of Pretoria); the research for this paper was done in partial fulfilment of an LLM degree at the University of Pretoria, whilst working as an academic associate in the Department of Legal History, Comparative Law and Legal Philosophy at the University of Pretoria.

1 Nagel et al Commercial Law (2006) 401.

As above.

Act 24 of 1936.

T Wier A history of private law in Europe: With particular reference to Germany (1995) 226. 


\section{Relevance of ancient Rome}

Economic development and academic institutions were essentially initiated in Northern Italy and progressively spread over Europe. ${ }^{5}$ This resulted in Roman law becoming the basis of all studies of law. 6 Roman law was consequently taught at Leiden University in Holland. ${ }^{7}$

In 1652, Van Riebeeck under the authority of the VOC, arrived in Cape Town, South Africa. ${ }^{8}$ Cape Town was regarded by the international community as being res nullius, ${ }^{9}$ and the VOC could thus gain ownership by merely occupying the land. Consequently Van Riebeeck's arrival laid a sound foundation for Roman Dutch Law in South Africa. ${ }^{10}$ In September 1795 the rule of the VOC ended by the British conquest of the Cape. ${ }^{11}$ This did not, however, lead South Africa to relinquish Roman-Dutch law. ${ }^{12}$

One can thus deduce that Roman law is the skeleton of our modern insolvency law in South Africa, and the study and understanding of the history and development is pivotal in grasping contemporary legislation. An exposition of Roman law will now commence, aiming to uncover the way of life and reasoning of the ancient Roman civilisation.

\section{$3 \quad$ Milestones of insolvency law}

Four landmarks can be identified throughout this timeline, each of which indicates the development of insolvency law. The legis action per manus iniectionem found in the Twelve Tables represents the first of these milestones.

\subsection{Legis actio per manus iniectionem}

A class struggle between the plebeians - citizens with no political or social rights - and patrician - wealthy and influential aristocrats tainted the first half of the republican period. ${ }^{13}$ The source of the struggle could be found in the fact that those with no political standing carried no knowledge of the law. ${ }^{14}$ The struggle ultimately

\footnotetext{
Thomas et al Historical foundations of South African private law (2002) 55.

Thomas et al (n 5 above) 68.

Thomas et al (n 5 above) 55 .

As above.

A res nullius refers to a thing without owner.

Thomas et al (n 5 above) 95.

Thomas et al (n 5 above) 96.

Campbell v Hall 17741 All ER 252. This case laid down the precedent for the continuation of the legal status quo, namely Roman-Dutch law.

13 Thomas et al (n 5 above) 18.

14 As above.
} 
led to the first codification of law, namely the Twelve Tables in 450 $\mathrm{BC} .15$

Subsequently twelve wooden tablets were posted in the market place, laying out the laws to be followed by all Roman citizens. ${ }^{16}$ The importance of the Twelve Tables with regards to the 'advantage of the creditors' requirement and insolvency law can be illustrated by the following passage:

A person who admits to owing money or has been adjudged to owe money must be given 30 days to pay. After then, the creditor can lay hands on him and haul him to court. If he does not satisfy the judgment and no one is surety for him, the creditor may take the defendant with him in stocks or chains 15 pounds in weight, he may not restrain him in greater but if he wishes in less. The debtor may live where he wishes. If he does not live on his own, the creditor must give him a pound of wheat a day. If he wants to he may give more. On the third market day, [creditors] may cut pieces. If they take more than they are due, they do so with impunity.

It is thus clear from the above quote that the Twelve Tables permitted the use of a person's body, which is 'human flesh', as collateral for debt. ${ }^{17}$ This brought about equality amongst creditors as they could each be entitled to a portion of such 'flesh' as recuperation for their debt.

The question now arises whether this method of debt collecting is to the advantage of the creditors. It could be argued that although the division of flesh of the debtor brought about no economical value, it served as deterrence for non-performance by current and prospective debtors. In a nutshell it could thus be deduced that the division of the human physique served as the procedure for insolvency law, to enable an individual to pay his debt when his liabilities exceeded his assets, and the only asset remaining was his flesh.

Personal execution is seemingly to the advantage of the creditors and intertwined with the ideology of concursus creditorum. Following the above mentioned procedure, the second milestone developed, namely the nexum, mortgage of the body.

\subsection{Nexum}

During the early republic a kind of voluntary mortgage, called nexum, developed. ${ }^{18}$ According to this contract, entered into by means of

As above.

As above.

C Visser 'Romeinsregtelike aanknopingspunte van die sekwestrasieproses in die Suid- Afrikaanse insolvensiereg' (1980) De Jure 44.

18 TC Albert 'The insolvency law of ancient Rome' (2006) 28 California Bankruptcy Journal 5. 
mancipatio, a creditor could capture the debtor and hold him as a slave if he was in default with regards to his obligations. ${ }^{19}$

The law evolved from a non-economical advantage for the creditor to an economical advantage. ${ }^{20}$ This evolution could be explained by a subjective shift in intention: a shift from a procedure developed to punish a defaulting debtor to a voluntary mortgage procedure developed to secure performance. ${ }^{21}$ Roman citizens showed antagonism towards this development of law, due to the fact that it stripped children of their youth and embodied a creditor's lust and cruelty. ${ }^{22}$ An outcry was subsequently made to the senate to change the law. ${ }^{23}$ The Lex Poetelia Papiria was thence enacted, abolishing enslavement and execution of debtors. ${ }^{24}$

The importance of this development is vested in the fact that thenceforth only a debtor's goods could be mortgaged as security for debt. Although the nexum ascertained an economical advantage for the creditor, it by no means led to equality between creditors.

Due to the abolition of enslavement, the mortgage of goods as security needed to be developed by the citizens. Missio in bona is the third milestone in the development of insolvency law.

\subsection{Missio in bona}

Missio in bona was an order given by the praetor which allowed the creditors to obtain possession of all the assets of the debtor. ${ }^{26}$ This application to the praetor could be made either by one or more of the creditors or by the debtor personally. ${ }^{27}$

An application made by the creditors was called missio in possessionem. ${ }^{28}$ Interestingly enough, the requirements for the creditors to bring this application did not include proof of the debtor's insolvency. ${ }^{29}$ After the relevant time periods had lapsed and the public announcement of commencement of the bonorum venditio had taken place, a meeting of the creditors was called. ${ }^{30}$ One creditor out of all the creditors at the meeting was then appointed magister

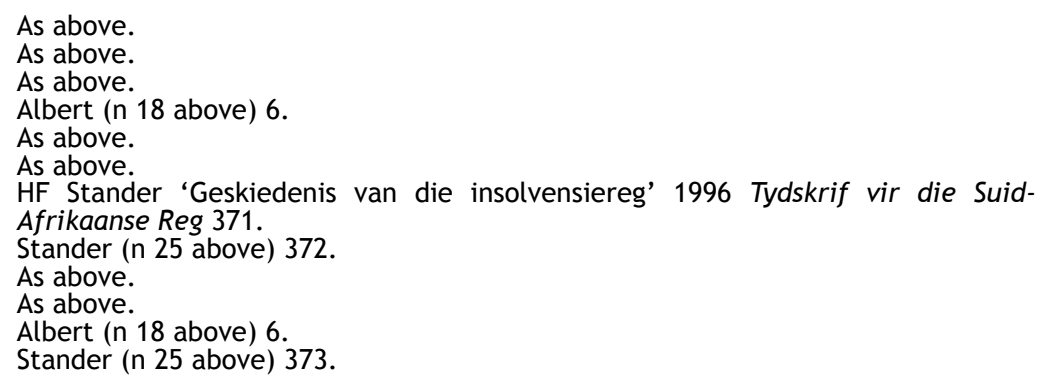


bonorum. ${ }^{31}$ Once a magister bonorum was appointed, the debtor became infamis. 32

The magister bonorum did not obtain ownership of the assets. ${ }^{33}$ His appointment merely enabled him to sell all the assets of the debtor to the highest bidder, ${ }^{34}$ known as the bonorum emptor. ${ }^{35}$ The bonorum emptor only obtained 'bonitary ownership'. ${ }^{36}$ He had to pay the creditors according to their claim. ${ }^{37}$ Firstly, the mortgage creditors were paid in full, followed by the privileged creditors, ${ }^{38}$ and lastly the other creditors. ${ }^{39}$ It is crucial to note that if the proceeds of the estate were insufficient to pay all debt, the debtor remained liable for any deficiency. 40

The only advantage the debtor obtained was that of beneficium competentiae, ${ }^{41}$ according to which he had the right not to be prosecuted for new assets obtained for the duration of one year after sequestration. 42

From the above it is clear that compulsory sequestration in ancient Rome provided no release from debt once the relevant procedure was instituted. The creditors, unlike today, had no duty bestowed upon them to prove that this action would be to their advantage. A simplistic explanation for this could be that there was in fact no need for this process. Missio in possessionem was already to the advantage of all the creditors, since the debtor was not released from his debt.

An application could also be made to the praetor by the debtor. This was known as cessio bonorum or Lex Julia de bonis cendenis (Lex Julia). It remains unclear whether this action was developed by Julius Ceasar or Augustus. ${ }^{43}$ This procedure could only be brought in the case where the debtor had no fault for being unable to fulfil all his obligations. ${ }^{44}$ It was seen as a privilege only available to deserving

As above.

$M$ Roestoff 'Skuldverligtingsmaatreels vir individue in die Suid-Afrikaaanse insolvensiereg: ' $n$ historiese ondersoek' (2004) Fundamina 123.

Stander (n 25 above) 372.

JW Wessels History of Roman Dutch Law (1908) 662.

Stander (n 25 above) 372.

As above.

As above.

Eg the wife, and the persons who paid the funeral expenses; Wessels (n 34 above) 662.

Wessels (n 34 above) 662

Roestoff (n 32 above) 123.

As above.

As above.

JQ Witman 'The moral menace of Roman law and the making of commerce: Some Dutch evidence’ (1996) 105 Yale Law Journal 18. 
debtors. ${ }^{45}$ These deserving debtors obtained the advantage of keeping all their fame and reputation, also known as infamia. ${ }^{46}$

In the later middle ages a new kind of cessio bonorum was revived, one known by us to be accompanied by a sanction of dishonour. ${ }^{47}$ In addition to all the previous formalities, a debtor was required to declare his insolvency at the 'rock of shame'. ${ }^{48}$ In short the debtor had to strike his rear three times against a rock, completely naked, and declare his insolvency. ${ }^{49}$ No one can pinpoint the exact reason for this added requirement. It was however contemplated to be in the logic of justice, since it grants the debtor immunity from imprisonment and a full discharge. ${ }^{50}$

Another important point to note is the fact that the magister was appointed out of one of the creditors with the primary motive of bringing benefit to him and the creditors who elected him. Public interest was insignificant and consequently ignored. ${ }^{51}$ During the reign of Justinian, however, another procedure evolved, namely the distractio bonorum.

\subsection{Distractio bonorum}

This procedure originated to assist clara persona. ${ }^{52}$ The senate, by decree, would appoint a curator to sell only that portion of the debtor's goods necessary to satisfy the creditors. ${ }^{53}$ This procedure could only be implemented if the debtor had a minimum of two creditors and was insolvent. 54

A very important development was that once this procedure was complete, creditors had no claim on assets which the debtor obtained in the future. ${ }^{55}$ Upon application, in terms of missio in possessionem or cessio bonorum, ${ }^{56}$ the praetor appointed a curator bonorum. ${ }^{57}$ The curator bonorum represented public interest, and had no personal interest in the matter. ${ }^{58}$

Distractio bonorum bears a strong resemblance to modern insolvency law, since a minimum of two debtors are required and the

Albert (n 18 above) 3; Roestoff (n 32 above) 126.

Stander (n 25 above) 372 .

As above.

As above.

Whitman (n 43 above) 20.

As above.

Stander (n 25 above) 372.

This refers to an 'illustrious person'; Stander, as above.

Stander (n 25 above) 372.

Stander (n 25 above) 373.

As above.

The debtor also retained his infamia with the distractio bonorum procedure.

Stander (n 25 above) 373.

As above. 
debtor had to be insolvent. Distractio bonorum is the basis of South African insolvency law, seeing as it is the first collective debt collecting process. ${ }^{59}$

\section{Conclusion}

History as a whole is an ongoing, gradually developing revelation of the absolute and the architect of the organism the sculptor of the work of art, in which the divine idea of law reveals itself. ${ }^{60}$

History is explored in an attempt to clarify the present state of law by showing its evolution over time. The aim of this exposition of ancient Roman law was to find an understanding of contemporary insolvency law and more specifically sections 6(1) and 12(1)(c) of the Insolvency Act. According to these sections, a prerequisite for sequestration compulsory or voluntary - is that it should be or would be to the advantage of the creditors. The question that needs to be answered is why sequestration should be to the advantage of the creditors at all.

The legis actio per manus iniectionem procedure symbolises the beginning of debt collecting. This time period was characterised by the sweat and blood of defaulting debtors. These debtors received the most horrific punishment imaginable for not paying their dues.

The lack of a procedure to aid debtors in these most unfortunate predicaments led to each creditor taking his share of the debtor's estate - in this case his body - to settle their debt. The advantage obtained was simply satisfaction of punishment linked with a warning to other debtors. The reasons for non-performance were irrelevant. A clear message was sent that whenever a debt is due, the law takes no cognisance of rhyme or reason; it simply favours the creditors.

Mortgage of a debtor's body rapidly followed. The law saw no problem with enslavement for a debt. They justified imprisonment of children, with the notion of justice towards creditors. An outcry by citizens to banish the laws that allowed the harshest punishment for defaulting creditors led to a law stating that only a debtor's property could be seized by creditors. This movement indicated a step in the right direction. The law began to recognise rights of the debtor.

The procedure implemented to deal with this new law of seizing a debtor's property reinforced the principle that the whole debt collecting procedure in its entirety was designed to function only for the benefit of the creditors. It is submitted that this is due to the fact that the magister in the case of missio in posessionem was a creditor, 
and acted with the sole intention of benefiting himself and fellow creditors.

During the reign of Augustus more attention was given to the rights of debtors. This is illustrated by the enactment of cessio bonorum. According to this procedure a debtor could keep his infamia, which is usually lost during the various preceding debt collecting procedures, if his debt problems could be attributed to hard luck without any fault by the debtor. He was, however, liable for full payment of all debt. So even though a debtor did not lose his reputation, the primary goal was still to benefit the creditor.

Distractio bonorum came to the benefit of the debtor as well as the creditor, as the curator bonorum only sold assets as far as was needed to settle the debt. According to this procedure, creditors had no claim on assets obtained in the future.

One can thus clearly see a development of the law from being completely creditor-orientated to a more debtor-friendly system affording the debtor rights. It is submitted that the requirements exist to guarantee that the objective of the debt collecting system is complied with. The objective of this is to establish a system to the sole advantage of the creditors; to guarantee successful and efficient debt collecting.

Initially the requirements were not needed to guarantee the objective of the sequestration procedure, but the more rights debtors obtained the more the need for the requirements existed. It is submitted that a balance should be struck between the interests of the debtor and the creditor respectively. Insolvency law should be approached and implemented with the idea of it being a tool assisting both the creditor and the debtor to find the best solution to any problem arising from debt collection. The objective of benefiting the creditor could remain in force whilst protecting a debtor from public humiliation, enslavement and, as we have seen, death. 